\title{
ANALYSIS OF AUTOMATED SOFTWARE FOR MONITORING ENERGY CONSUMPTION AND EFFICIENCY OF INDUSTRIAL ENTERPRISES
}

\author{
I U Rakhmonov ${ }^{1}, \mathrm{~N}$ N Kurbonov ${ }^{1}$ \\ ${ }^{1}$ Tashkent state technical university, Tashkent.
}

\begin{abstract}
There are a number of programs that perform analyzes on energy types. One of the current issues is to study their properties and bring them into a single system. In this article, we demonstrated the available capabilities, benefits, and limitations of energy resource management programs. We analyzed which operating system the energy management software runs on, the availability of mobile and site versions, which industry it belongs to, and the cost. Measurement results show that while the program with the highest score was Wattics, the features in other programs are not available in this program. Finally, it is important to create a single database that integrates all the data in these processes and to create a program based on a single system that manages this database.
\end{abstract}

\section{INTRODUCTION}

According to the statistics, global power generation, which had increased by nearly $3 \% /$ year over the 2000-2018 period, slowed down significantly in
$2019(+1 \%)$ and global electricity consumption grew at a much slower pace than in recent years $(+0.7 \%$ compared to an average $3 \% /$ year over the 2000-2018 period) (pic.1.). [1] According to 2016 data, Uzbekistan has $1,628 \mathrm{kWh}$ of energy per capita.

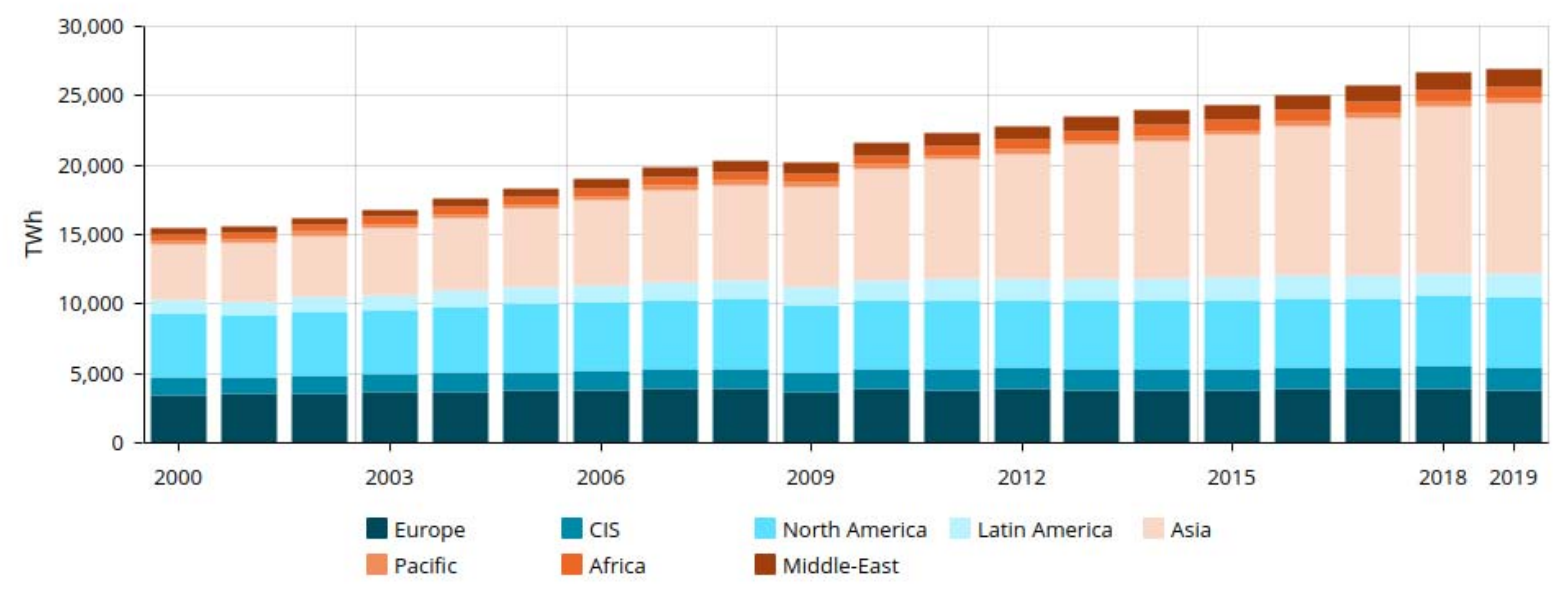

Pic.1. Energy production over the world during 2000-2019 


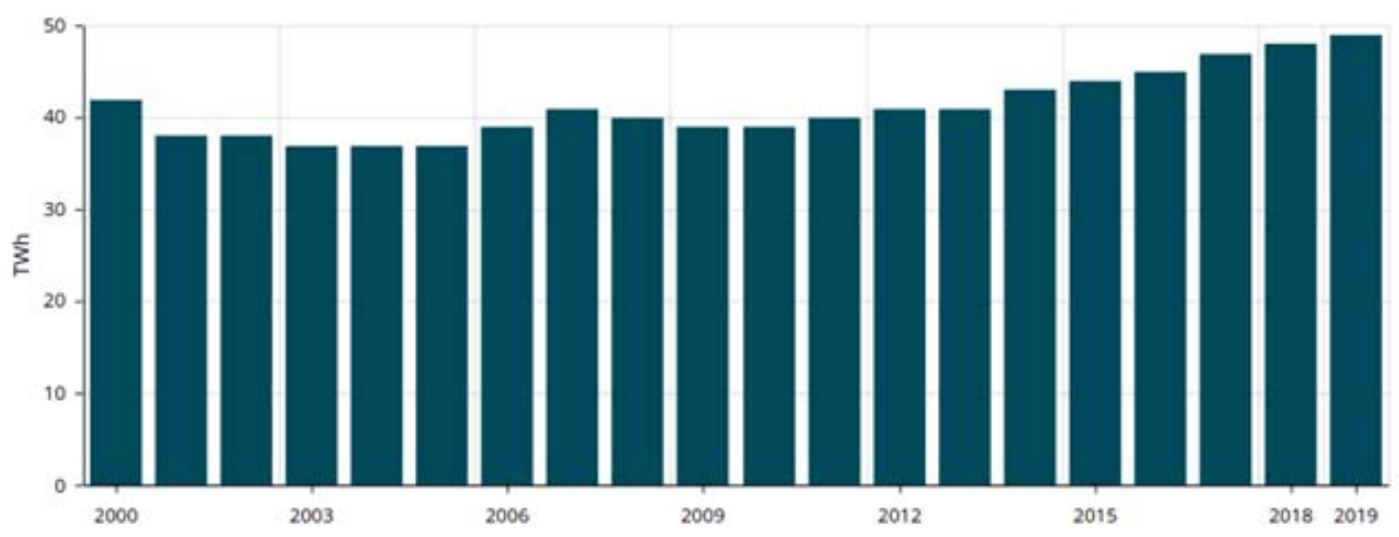

Pic.2. Energy production in Uzbekistan during 2000-2019

On the report of international experts (VL Ganja), oil reserves from conventional reserves will last for 41 years, natural gas for 62 years, and coal for 230 years. Also Uzbekistan's coal reserves will last for 40-50 years, oil for 10-12 years and natural gas for 28-30 years. [2] It seems that it is important to pay more attention to prevention of wasteful use of energy and energy efficiency, not only in Uzbekistan but also around the world. Many programs have been developed to address this issue. However, in the last few years, researchers started paying attention to the energy impact of software because software activities have a direct influence on the energy consumption of hardware underneath. $[3,4]$

We know that each of the processes of energy production, their delivery to the consumer or the production of products using electricity in industrial enterprises are very comprehensive areas. Accordingly, software is being developed for the specific industries, and it is important to categorize and analyze them.

The rest of the paper is organized as follows. In section 2 , we give a brief information the various types of applications. In Section 3, we will compare their operating principles, functions, advantages and disadvantages sides by analysis table. In Section 4, as part of the result, we explain some ways how to overcome the shortcomings. Some concluding remarks are provided in the last Section.

\section{SOFTWARES}

There are many additional benefits of reducing energy costs and energy use with energy management software, but these often go unnoticed by decision-makers when it comes time to consider adopting a new technology. From energy production, there are several types of software that calculate its consumption, analyze results, reveal shortcomings, and develop recommendations. Here is some of the most widely used software today: Power SCADA Operation 8.2, Monitoring Expert 8 are offered by the company Schneider Electric, Wattics is offered by the company Wattics, XClarity Energy Manager, ETAP Energy Management System, OpenDEM, EnergyCAP, Waterfield Energy Software, SSI Energy Management System, N'VIEW.

\subsection{POWER SCADA OPERATION 8.2}

EcoStruxure TM Power Monitoring Expert software is a complete energy management system that aggregates plant distribution data and presents it as meaningful information through an intuitive web interface. EcoStruxure Power Monitoring Expert's open architecture uses industry standard protocols and allows you to work with any device. The software can be easily integrated with any accounting, monitoring and automation systems (for example, SCADA, BAC, DCS, ERP), as well as web services.

\subsection{POWER MONITORING EXPERT (PME)}

PME is a suite of supervisory control software products designed to simplify energy management applications. The proposed software allows you to collect and organize data received from power equipment, and then present them as intuitive information, which, in turn, is of great practical value, through the use of web technologies.

Presentation of data in PME for management personnel is reduced to the output of simple and understandable graphs (reports) reflecting the economic efficiency of the energy facilities. [6]

\subsection{WATTICS}

Wattics is web-based energy management software that connects to smart meters, sensors, and business data to provide the analytics you need to keep your 
business energy efficient. Wattics provides energy analytics tools that are designed for use by energy consultants, utilities, and business executives. These tools can help improve performance by looking at usage performance among all your companies utilities such as water, electricity, stream, and more. These meters and readings help identify periods of high stress and usage and can identify when energy is being wasted, leading to savings and sustainability in the long-run. [7]

\subsection{XCLARITY ENERGY MANAGER}

Lenovo XClarity Energy Manager is a centralized policy-based system energy management solution. The software helps track, manage, and plan server power utilization. [8]

\subsection{ETAP ENERGY MANAGEMENT SYSTEM}

ETAP is an energy management system that was designed to reduce the use of energy, improve the utilization of any system it's monitoring, predict the performance of your electrical systems, and optimize energy usage to help reduce cost. [8]

\subsection{ENERGYCAP}

Using EnergyCAP is doing energy management right. Of the many benefits of EnergyCAP, perhaps getting a handle on your energy information is the most important. Energy is your organization's most controllable operating expense, but you can't control it unless you track it. Track your energy with the most comprehensive web-friendly clientserver software on the market-with EnergyCAP. [8]

\subsection{WATERFIELD ENERGY SOFTWARE}

Waterfield Energy Software is a suite of software systems that handles all of your oil and gas accounting and transaction management needs for both the upstream and midstream verticals of the oil and gas industry, including drilling reporting systems. [8]

\subsection{SSI ENERGY MANAGEMENT SYSTEM}

The SSI Energy Management System is a highly reliable, robust and integrated series of applications developed for energy related enterprises. The applications were specifically designed for Operators, Non-Operators, Royalty Owners, Drilling Companies, Supply Companies, and Service Companies.
The products are designed to provide a flexible, scalable and full-featured energy management solution. The SSI System maximizes user flexibility and scalability, and allows straightforward integration with other applications. The goal is Making Your Job Easier. [8]

\subsection{N'VIEW}

The N'VIEW online service offers easy and intuitive analysis of energy consumption regardless of the business sector (industry, building, infrastructure...). Compatible with the main market communication gateways including Socomec devices (DIRIS G, DIRIS Digiware D-70 and DATALOG H80 / 81), N'VIEW platform ensures that multi-utility data is collected. From the identification of potential energy savings to longterm performance tracking and investment validation, N'VIEW offers a complete package of services for efficient energy management. To meet specific requirements, the N'VIEW platform can also interface with other energy management applications (Energy Apps) which are already available or can be created on demand.

\section{METHODOLOGY}

The convenience of the application is characterized by the distance or measurement from side to side of the working environment in it. In a way that is appropriate to the particular circumstances, we evaluated these programs according to the following characteristics:

$>$ Operation system - what operation system is it compatible with. (max score - 10) (Windows, Linux, MacOS - max score - 1)

$>$ Mobile application - is there a mobile version. (max score -10$)$

$>$ Web version - is there a mobile version. (max score - 10)

$>$ Payment - is there a fee for using the software. (max score - "-10")

$>$ The type of application field or accounting - usage field of the software and what parameters it is suitable for the calculation:

Management - $(\boldsymbol{m a x}$ score -10$)$

Taking into account the type of energy:

Electrical energy - $(\max$ score -1$)$

Thermal energy - $(\max$ score -1$)$

Gas - (max score - 1$)$

cold and hot water - $(\max$ score -1$)$

drainage - $(\max$ score -1$)$ 
The diagram of line - the presence of a

the account $-(\max \operatorname{score}-20)$ line diagram of the system that is part of

ANALYSIS TABLE

\begin{tabular}{|c|c|c|c|c|c|c|c|c|}
\hline № & $\begin{array}{c}\text { Names of } \\
\text { applications }\end{array}$ & $\begin{array}{l}\text { Operation } \\
\text { system }\end{array}$ & $\begin{array}{c}\text { Mobile } \\
\text { application }\end{array}$ & $\begin{array}{c}\text { Web } \\
\text { version }\end{array}$ & Payment & $\begin{array}{l}\text { The type of } \\
\text { application } \\
\text { field or } \\
\text { accounting }\end{array}$ & $\begin{array}{c}\text { The } \\
\text { diagram } \\
\text { of line }\end{array}$ & $\begin{array}{l}\text { Full } \\
\text { score }\end{array}$ \\
\hline 1. & $\begin{array}{l}\text { Power SCADA } \\
\text { Operation } 8.2 \text {, }\end{array}$ & Windows & - & - & + & $\begin{array}{l}\text { management } \\
\text { and control of } \\
\text { electricity } \\
\text { distribution } \\
\text { networks }\end{array}$ & + & 40 \\
\hline 2. & $\begin{array}{c}\text { Power } \\
\text { Monitoring } \\
\text { Expert (PME) }\end{array}$ & Windows & + & - & + & $\begin{array}{l}\text { Management } \\
\text { and control of } \\
\text { electricity; } \\
\text { thermal } \\
\text { energy; } \\
\text { gas; } \\
\text { cold and hot } \\
\text { water; } \\
\text { drainage; }\end{array}$ & + & 54 \\
\hline 3. & Wattics & windows & + & + & + & $\begin{array}{c}\text { Energy } \\
\text { management }\end{array}$ & - & 59 \\
\hline 4. & $\begin{array}{c}\text { XClarity Energy } \\
\text { Manager }\end{array}$ & windows & + & + & - & $\begin{array}{c}\text { Energy } \\
\text { management }\end{array}$ & - & 40 \\
\hline 5. & $\begin{array}{l}\text { ETAP Energy } \\
\text { Management } \\
\text { System }\end{array}$ & windows & - & - & - & $\begin{array}{c}\text { Energy } \\
\text { management } \\
\text { and } \\
\text { Advanced } \\
\text { distribution } \\
\text { management } \\
\text { system } \\
\end{array}$ & + & 50 \\
\hline 6. & EnergyCAP & Windows & - & + & + & $\begin{array}{c}\text { Energy } \\
\text { management } \\
\text { and utility } \\
\text { billing }\end{array}$ & - & 39 \\
\hline 7. & $\begin{array}{c}\text { Waterfield } \\
\text { Energy Software }\end{array}$ & $\begin{array}{l}\text { Windows, } \\
\text { Mac }\end{array}$ & - & + & - & $\begin{array}{c}\text { Oil gas and } \\
\text { energy } \\
\text { management }\end{array}$ & + & 54 \\
\hline 8. & $\begin{array}{c}\text { SSI Energy } \\
\text { Management } \\
\text { System, }\end{array}$ & Windows & - & - & + & $\begin{array}{c}\text { Oil gas and } \\
\text { energy } \\
\text { management }\end{array}$ & - & 22 \\
\hline 9. & N'VIEW. & Windows & - & - & - & $\begin{array}{l}\text { analysis of } \\
\text { energy } \\
\text { consumption }\end{array}$ & + & 40 \\
\hline
\end{tabular}




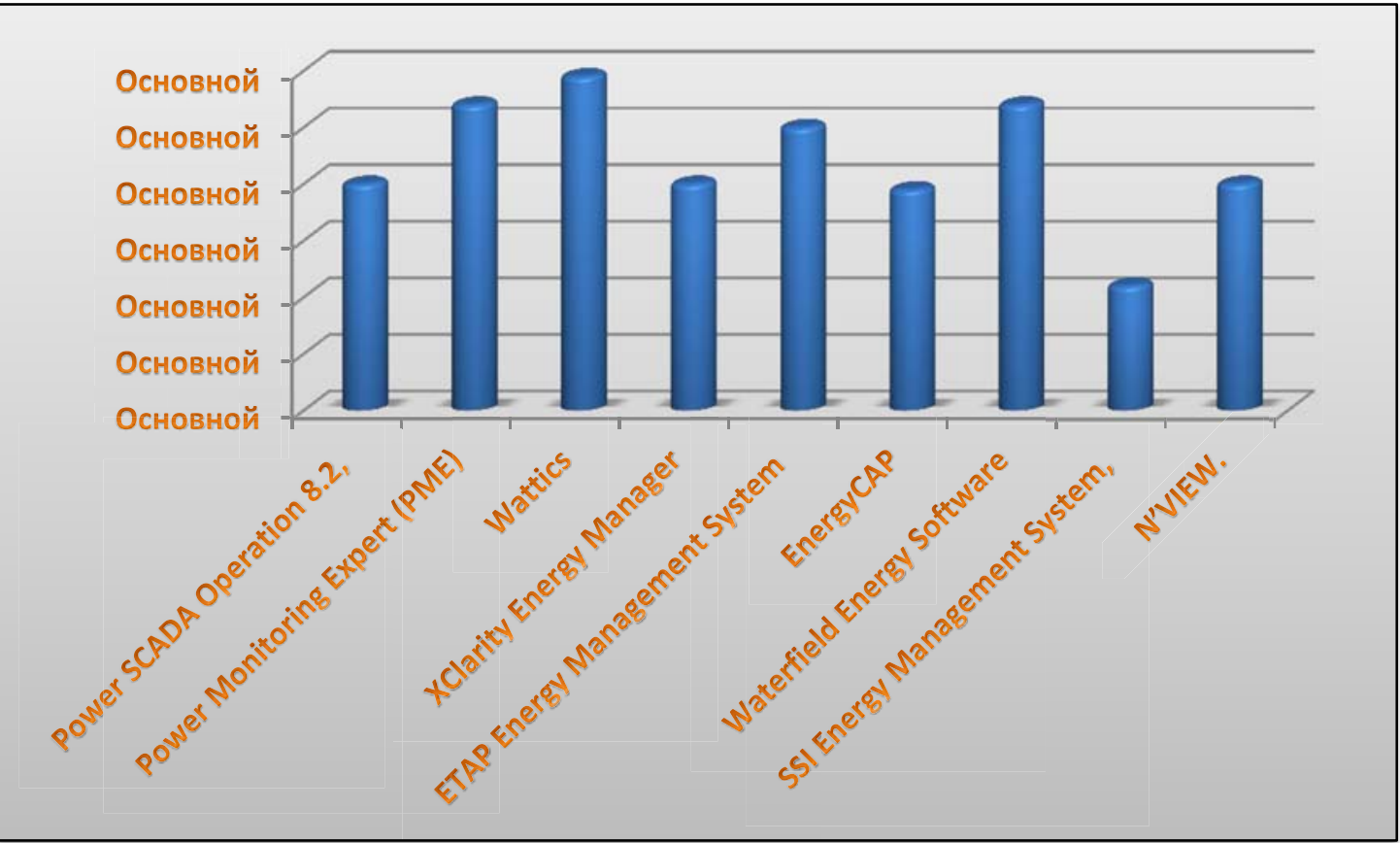

Diagram 1. Score diagram of applications

\section{Result}

Which options have all of the above features and benefits, plus a little extra? We've done some research and found some of the best energy management software option is Wattics. Wattics has one of the widest ranges of intelligent energy analytics tools available in their program compared to other available options on the market. Some of their best features include monitoring consumption and costs, customized alerts, scheduled reports, and machine learning capabilities. Wattics is a very visually appealing solution, and they even offer a branded page capabilities. This means a more professional looking system in line with your company standards. Wattics ranks as high as it can in terms of being user-friendly and intuitive. [8]

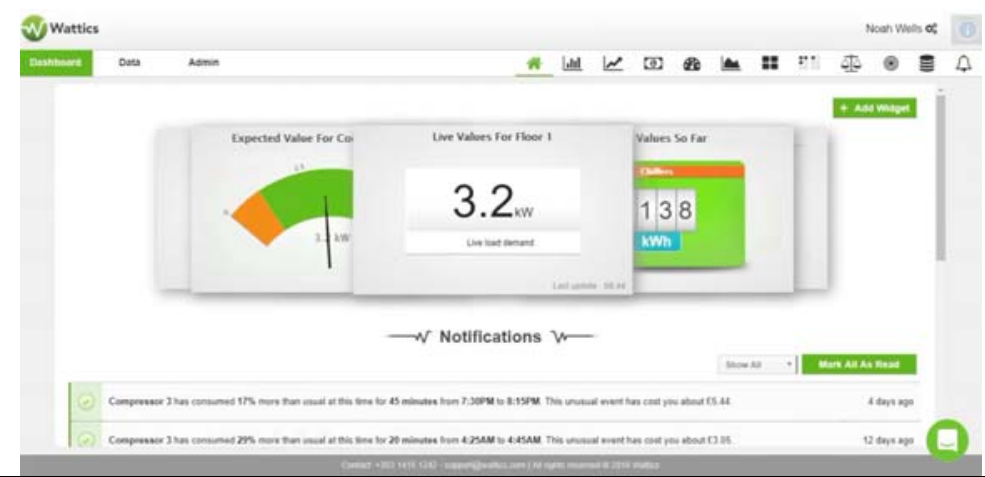

Pic.3. The Interface of Wattics

Energy management software is a great tool for improving energy efficiency. There are many proprietary systems on the market ready to go off the shelf, so you can purchase the licensed modules you need, plug in the connections and data feeds, and then you're done. However, software is just a tool that should be used skillfully to get the best results; for this you need to take the initiative, if you are passive - the results will pass you by.
Energy management software can combine all the energy consumption data of your building systems into one application. Lighting, security systems and other production equipment can be incorporated into the system by presenting it on a visual panel. This allows energy consumers to view the energy consumption of buildings and get an idea of the energy consumption of each system. 
In my opinion, software should be seen as a tool, very smart and capable, but a tool nonetheless. You will go to a mechanic you trust because he is good at what he does, you don't care what type of wrenches or diagnostic equipment he uses, you buy his knowledge.

\section{CONCLUTION}

In this paper, first we give a brief information some types of energy management applications. We demonstrated the available capabilities, benefits, and limitations of energy management programs. We performed actual measurement of all features that are which operating system the energy management software runs on, the availability of mobile and site versions, which industry it belongs to, and the cost of usage. As can be seen from the analysis table, Wattics is one of the best software, but also the features of others are important. From the process of energy production to the process of consuming it, the processes are interrelated. it is important to create a single database that integrates all of the data in these processes and to create a program based on a single system that manages this database.

\section{REFERENCES}

1. https://yearbook.enerdata.net

2. Offical site of Ministry of economic development and poverty reduction of the republic of uzbekistan (C) 2008-2020

3. E. Capra, C. Francalanci, S.A. Slaughter. Is software green? application development environments and energy efficiency in open source applications. Information and Software Technology 2012;54(1):60-71.

4. A. Noureddine, A. Bourdon, R. Rouvoy, L. Seinturier. A preliminary study of the impact of software engineering on greenit. In: Green and Sustainable Software (GREENS), 2012 First International Workshop on. IEEE; 2012, p. 21-27.

5. https://www.se.com

6. http://sibit-projects.ru

$7 . \quad$ www.wattics.com

8. softwareconnect.com 